\title{
บUsisersily
}

\section{Enhanced probiotic viability and aromatic profile of yogurts produced using wheat bran (Triticum aestivum) as cell immobilization carrier}

Terpou, A., Bekatorou, A., Kanellaki, M., Koutinas, AA., \& Singh - Nee Nigam, P. (2017). Enhanced probiotic viability and aromatic profile of yogurts produced using wheat bran (Triticum aestivum) as cell immobilization carrier. Process Biochemistry, 55, 1-10. https://doi.org/10.1016/j.procbio.2017.01.013

Link to publication record in Ulster University Research Portal

\author{
Published in: \\ Process Biochemistry
}

Publication Status:

Published online: 17/01/2017

DOI:

10.1016/j.procbio.2017.01.013

\section{Document Version}

Publisher's PDF, also known as Version of record

\section{General rights}

Copyright for the publications made accessible via Ulster University's Research Portal is retained by the author(s) and / or other copyright owners and it is a condition of accessing these publications that users recognise and abide by the legal requirements associated with these rights.

\section{Take down policy}

The Research Portal is Ulster University's institutional repository that provides access to Ulster's research outputs. Every effort has been made to ensure that content in the Research Portal does not infringe any person's rights, or applicable UK laws. If you discover content in the Research Portal that you believe breaches copyright or violates any law, please contact pure-support@ulster.ac.uk. 


\title{
Enhanced probiotic viability and aromatic profile of yogurts produced using wheat bran (Triticum aestivum) as cell immobilization carrier
}

\author{
Antonia Terpou ${ }^{\mathrm{a}, *}$, Argyro Bekatorou $^{\mathrm{a}}$, Maria Kanellaki ${ }^{\mathrm{a}}$, Athanasios A. Koutinas ${ }^{\mathrm{a}}$, \\ Poonam Nigam ${ }^{b}$ \\ a Food Biotechnology Group, Department of Chemistry, University of Patras, GR-26500, Patras, Greece \\ b School of Biomedical Sciences, University of Ulster, Cromore Rd., Coleraine BT62 1SA, Northern Ireland, United Kingdom
}

\section{A R T I C L E I N F O}

\section{Article history:}

Received 23 October 2016

Received in revised form 7 January 2017

Accepted 12 January 2017

Available online 17 January 2017

\section{Keywords:}

Probiotic yogurt

Wheat bran

Immobilization

GCMS/SPME

\begin{abstract}
A B S T R A C T
The effect of wheat bran (Triticum aestivum) as a cell immobilization carrier for probiotic yogurt production on cell viability, composition of volatile compounds and sensory characteristics, was studied. Wheat bran was delignified and separately used as a carrier for the immobilization of Lactobacillus casei ATCC393 and Lactobacillus bulgaricus DSM20081. Both biocatalysts were freeze-dried without the addition of cryoprotectants and were used for yogurt fermentation at $40{ }^{\circ} \mathrm{C}$. Their operational stability was evaluated during successive yogurt fermentation batches until they were inactivated. The yogurts fermented using the immobilized biocatalysts were compared with those fermented with free Lactobacillus cells and with conventional yogurt culture (Streptococcus thermophilus and L. bulgaricus). The novel yogurts showed significantly higher cell viabilities during storage at $4{ }^{\circ} \mathrm{C}$. In addition, the immobilized biocatalysts showed higher survival rates during exposure to simulated gastric juice ( $\mathrm{pH} 3.0$ ). The immobilized biocatalysts significantly affected the production of volatile compounds, indicating, in combination with the sensory evaluations, potential for good-quality probiotic yogurt production by freeze-dried ready-to-use immobilized starters.
\end{abstract}

(c) 2017 Elsevier Ltd. All rights reserved.

\section{Introduction}

Currently, there is an increase in interest for developing functional food products containing probiotic microorganisms combined with prebiotic ingredients. Such combinations demonstrate a great potential in promoting human health and can easily be provided to the consumer by incorporation into dairy products such as yogurt [1-3]. Yogurt is a fermented dairy product consumed worldwide. It has a high nutritional value with well-established health benefits, especially when reinforced with prebiotic ingredients and probiotic bacteria [1-4]. Traditionally, yoghurt is produced from milk by the synergistic action of lactic acid bacteria (LAB) such as Lactobacillus delbrueckii ssp. bulgaricus and Streptococcus thermophilus [5]. The addition of beneficial probiotic bacteria (bifidobacteria and lactobacilli) to yogurt presents a challenge, basically because of their interaction with other microbial species present in yogurt and sensitivity to yogurt constituents, processing, and storage conditions ( $\mathrm{pH}$, temperature, lactic acid concentration, oxygen, micronutrients, etc.), which might lead to important losses in cell

\footnotetext{
* Corresponding author.

E-mail address: ant.terpou@gmail.com (A. Terpou).
}

viability [4]. To deliver the health benefits to the consumer, it is utmost important to maintain viable probiotic cells in a product until consumption, at the minimum level usually ranging from $10^{6}$ to $10^{9} \mathrm{cfu} \mathrm{mL}^{-1}$ [5], to survive the acidic conditions of the upper gastrointestinal (GI) tract and proliferate in the intestine.

To enhance probiotic cell viability, several methods have been proposed, such as use of an appropriate administration matrix and microencapsulation techniques [4,6,7], cell immobilization [8-10], addition of prebiotics [9], and use of mixed starters [11]. Furthermore, there is an increasing trend for application of synbiotics (the combined use of probiotics and prebiotics) in functional food products. Prebiotics can increase the survival rates and stability of probiotics during processing and storage, especially when the cells are used in an immobilized state (with the prebiotic as the immobilization carrier) $[8,12]$.

Cereal dietary fibers can exert several beneficial physiological effects because of their content of specific non-digestible carbohydrates and can act as prebiotics promoting the growth and survival of probiotic species $[1-3,8,9,12]$. Wheat bran, an edible material containing dietary fiber, protein, inorganic elements, fat, and antioxidant components $[8,12,13]$, was used in the present study as a prebiotic immobilization carrier for probiotic yogurt cultures. Specifically, the objective of the present study was to develop and 
evaluate freeze-dried, ready-to-use biocatalysts by immobilization of Lactobacillus casei ATCC 393 and Lactobacillus delbrueckii subsp. bulgaricus on wheat bran for probiotic yogurt production.

\section{Materials and methods}

\subsection{Starter cultures and immobilized biocatalysts preparation}

The probiotic strain L. casei ATCC 393 (L. casei henceforth) and the strain L. delbrueckii subsp. bulgaricus DSM 20081 (L. bulgaricus), isolated from Bulgarian yogurt (DSMZ, Braunschweig, Germany), were grown at $37^{\circ} \mathrm{C}$ and $45^{\circ} \mathrm{C}$, respectively, for $48 \mathrm{~h}$ on de Man, Rogosa, and Sharpe (MRS) broth (Fluka, Buchs, Switzerland). S. thermophilus was isolated from commercial freeze-dried yogurt culture (FD-DVS CH-1 - Yo-Flex, Chr. Hansen, Horsholm, Denmark) and was grown at $45^{\circ} \mathrm{C}$ in MRS medium for three generations before use. All cultures were harvested by centrifugation at $5000 \mathrm{rpm}$ for 10 min at $25^{\circ} \mathrm{C}$ (Sigma Laborzentrifugen GmbH, Germany).

Wheat bran (Triticum aestivum L.) was supplied by the company Kepenos Flour Mills S.A. (Patras, Greece). It consisted of approximately $20 \%$ protein, $7 \%$ ash, $5 \%$ lipids, and $50 \%$ dietary fiber of which $30 \%$ was arabinoxylan and $18 \%$ was starch; this composition was comparable with those of other bran types reported in the literature $[14,15]$. Wheat bran was delignified by alkali treatment [16] to increase the porosity of the biocatalyst by lignin removal. The delignified wheat bran (DWB) was dried overnight at $50^{\circ} \mathrm{C}$ until complete moisture removal and was divided in equal amounts of 5 g. L. casei and L. bulgaricus cells were separately immobilized on DWB. Immobilization was performed by mixing $1 \mathrm{~g}$ of harvested wet cell mass with $5 \mathrm{~g}$ of DWB in MRS broth and incubating at $37^{\circ} \mathrm{C}$ and $45^{\circ} \mathrm{C}$, respectively, for $48 \mathrm{~h}$. The biocatalysts were washed twice with sterile Ringer's solution (1/4 strength) for the removal of free cells. The immobilized biocatalysts were frozen to $-44^{\circ} \mathrm{C}$ at a cooling rate of $5^{\circ} \mathrm{Cmin}^{-1}$ [8]. The frozen samples were freezedried for $48-72 \mathrm{~h}$ at $5 \times 10^{-3}$ mbar and $-44^{\circ} \mathrm{C}$ in a Freeze Drying System, Freezone 4.5 (Labconco, Kansas City, Missouri, USA). Similarly, free cell cultures of $L$. casei, L. bulgaricus, and S. thermophilus were frozen and freeze-dried separately. No cryoprotectant was used during freeze-drying [9].

\subsection{Yogurt production}

Homogenized and pasteurized cow's milk (3.5\% fat, 13\% total solids, pH 6.7) was used for yogurt production. For the fermentation process, the milk was preheated to $90^{\circ} \mathrm{C}$ for $10 \mathrm{~min}$, cooled down to $40^{\circ} \mathrm{C}$, divided into eight equal portions ( $1000 \mathrm{~mL}$ each $)$, and placed in sterile glass beakers.

The first milk portion (C: Control) was inoculated with classical yogurt culture (S. thermophilus and L. bulgaricus, 1:1 proportion, $1 \%$ $\mathrm{w} / \mathrm{v}$ inoculum), the second (F) was inoculated with freeze-dried free $L$. casei and $L$. bulgaricus cells ( $1 \% \mathrm{w} / \mathrm{v}$ inoculum; $1: 1$ proportion), and the third (IM) was inoculated with the freeze-dried immobilized biocatalyst ( $L$. casei and L. bulgaricus cells immobilized on wheat bran; $1: 1$ proportion; $1 \% \mathrm{w} / \mathrm{v}$ inoculum) that remained in yogurt after fermentation. In the same manner, the fourth milk portion $\left(\mathrm{IR}_{1}\right)$ was inoculated with the immobilized biocatalyst ( $1 \%$ $\mathrm{w} / \mathrm{v}$ inoculums; $1: 1$ proportion), but it was removed from yogurt at the end of fermentation ( $\mathrm{pH} 4.6 \pm 0.05$ ) and was used for four more fermentation batches $\left(I_{2}, I_{3}, I R_{4}\right.$, and $\left.I R_{5}\right)$. The immobilized biocatalysts, which were contained in a thin sterile perforated fabric, were carefully removed from the product at the end of fermentation and were submerged into milk $\left(40^{\circ} \mathrm{C}\right)$ for the next fermentation batch. After the removal of the biocatalyst, the yogurts were allowed to set for $10 \mathrm{~min}$. When each fermentation process was completed, the yogurt sample was stored in the refrigerator $\left(4^{\circ} \mathrm{C}\right)$ for 30 days.

\subsection{Microbiological analysis of yogurt}

For the enumeration of viable cells, 10-g samples were collected from each yogurt at various time intervals $(1,5,15,21$, and 30 days) during storage at $4{ }^{\circ} \mathrm{C}$. The samples were suspended in $90 \mathrm{~mL}$ of sterilized Ringer's solution (1/4 strength), homogenized (Bagmixer 400, Model VW, Interscience), serially diluted (ten-fold), and subsequently plated on media selective for each strain. L. casei was enumerated on V-MRS agar containing 1\% vancomycin (Fluka, Buchs, Switzerland) after incubation at $37^{\circ} \mathrm{C}$ for $72 \mathrm{~h}[8,17]$. S. thermophilus was enumerated on M17 medium with $1 \%$ lactose after incubation at $45^{\circ} \mathrm{C}$ for $72 \mathrm{~h}$. L. bulgaricus was enumerated on MRS agar with $\mathrm{pH}$ adjusted to 5.2 and incubation at $45^{\circ} \mathrm{C}$ for $72 \mathrm{~h}$ [17]. Viable counts of total mesophilic bacteria were enumerated on plate count agar (Fluka, Buchs, Switzerland) after incubation at $30^{\circ} \mathrm{C}$ for $72 \mathrm{~h}$. Total enterobacteria were enumerated on violet red bile glucose agar (Fluka, Buchs, Switzerland) after incubation at $37^{\circ} \mathrm{C}$ for $24 \mathrm{~h}$. Staphylococci counts were performed on Baird Parker agar (Fluka, Buchs, Switzerland) after incubation at $37^{\circ} \mathrm{C}$ for $48 \mathrm{~h}$. Yeasts and moulds were determined by plating on potato dextrose agar (Fluka, Buchs, Switzerland) after incubation at $30^{\circ} \mathrm{C}$ for $72 \mathrm{~h}$. Cell counts were expressed as $\log \mathrm{cfu} \mathrm{g}^{-1}$ of yogurt.

\subsection{Simulated gastric digestive analysis of biocatalysts and yogurts}

To investigate the influence of stomach $\mathrm{pH}$ on the survival rate of the probiotic $L$. casei bacteria (free or immobilized on DWB), simulated gastric solution was prepared as previously described [18]. The simulated gastric solution contained $2.0 \mathrm{~g} \mathrm{~kg}^{-1}$ of $\mathrm{NaCl}$ and $0.3 \mathrm{~g} \mathrm{~kg}^{-1}$ of pepsin and had $\mathrm{pH}$ of 3.0 (adjusted by the addition of $5 \mathrm{~mol} \mathrm{~L}^{-1} \mathrm{HCl}$ ). Samples contained the following: $1 \mathrm{~mL}$ each of free freeze-dried $L$. casei cells (S1), immobilized freeze-dried $L$. casei cells (S2), yogurt (first day after completion of fermentation) with free $L$. casei (F) cells, and yogurt with immobilized L. casei and L. bulgaricus that remained in yogurt during storage (IM). The samples were placed in sterile glass tubes containing $99 \mathrm{~mL}$ of simulated gastric solution. The mixtures were then blended in a stomacher for $10 \mathrm{~min}$ and were placed in an incubator at $37^{\circ} \mathrm{C}$ for $120 \mathrm{~min}$ with periodic shaking. After 30, 60, 90, and $120 \mathrm{~min}$, the samples were removed from the incubator and were tested for viable cells counts on MRS agar (Fluka, Buchs, Switzerland), for biocatalyst samples, or MRS-V agar, for yogurt samples, after incubation at $37^{\circ} \mathrm{C}$ for $72 \mathrm{~h}$ [17].

\subsection{Physicochemical analysis}

The produced yogurts were analyzed for acidity, residual lactose, and the organic acids produced (Table 1). The $\mathrm{pH}$ values were measured using a digital pH meter (Hanna HI99161). The titratable acidity was determined by titrating $10 \mathrm{~g}$ of each yogurt sample (suspended in $20 \mathrm{~mL}$ deionized water) with $0.1 \mathrm{~N} \mathrm{NaOH}$ using phenolphthalein as indicator.

For the determination of the lactose content and organic acids, $5 \mathrm{~g}$ of yogurt samples were suspended in sterile deionized water to obtain a total volume of $200 \mathrm{~mL}$. The mixture was filtered and centrifuged at $4125 \mathrm{rpm}$ for $20 \mathrm{~min}$ (Shimadzu Application, No L213). For the determination of organic acids, the samples were treated with $40 \%$ trichloroacetic acid (TCA) for protein precipitation [19]. Briefly, $9 \mathrm{~mL}$ of the filtrate was mixed with $1 \mathrm{~mL} \mathrm{TCA}$, incubated at $4{ }^{\circ} \mathrm{C}$ for $24 \mathrm{~h}$, and then centrifuged for $30 \mathrm{~min}$ at $4{ }^{\circ} \mathrm{C}$. All the samples were filtered through $0.2 \mu \mathrm{m}$ nylon filters before analysis. 
Table 1

Sugars, organic acids, titratable acidity, and $\mathrm{pH}$ in yogurts during 30 days of storage at $4{ }^{\circ} \mathrm{C}$.

\begin{tabular}{|c|c|c|c|c|c|c|}
\hline Storage time & Lactose & Galactose & Lactic acid & Citric acid & Titratable acidity & $\mathrm{pH}$ \\
\hline days & $\% w / w$ & $\% w / w$ & $\% w / w$ & $\% w / w$ & $\% w / w$ as lactic acid & \\
\hline \multicolumn{7}{|c|}{ Yogurt produced using conventional S. thermophilus and L. bulgaricus culture (C) } \\
\hline 0 & 5.00 & nd & nd & 0.16 & 0.32 & 6.70 \\
\hline 1 & 3.34 & 0.57 & 0.73 & 0.25 & 0.80 & 4.60 \\
\hline 5 & 3.03 & 0.59 & 0.76 & 0.16 & 0.82 & 4.57 \\
\hline 12 & 2.84 & 0.62 & 0.79 & 0.21 & 0.86 & 4.52 \\
\hline 21 & 2.56 & 0.64 & 0.84 & 0.12 & 0.88 & 4.51 \\
\hline 30 & 2.55 & 0.66 & 0.87 & 0.17 & 0.91 & 4.50 \\
\hline \multicolumn{7}{|c|}{ Yogurt produced using free $L$. casei and $L$. bulgaricus cells $(F)$} \\
\hline 0 & 5.00 & nd & nd & 0.16 & 0.32 & 6.70 \\
\hline 1 & 2.54 & 0.66 & 0.86 & 0.24 & 0.81 & 4.58 \\
\hline 5 & 2.48 & 0.67 & 0.87 & 0.19 & 0.83 & 4.55 \\
\hline 12 & 2.16 & 0.72 & 0.93 & 0.22 & 0.85 & 4.54 \\
\hline 21 & 1.91 & 0.73 & 0.96 & 0.20 & 0.93 & 4.48 \\
\hline 30 & 1.88 & 0.77 & 1.16 & 0.11 & 0.97 & 4.42 \\
\hline \multicolumn{7}{|c|}{ Batch 1-Yogurt produced using immobilized L. casei and L. bulgaricus removed after fermentation $\left(I_{1}\right)_{1}$} \\
\hline 0 & 5.00 & nd & nd & 0.16 & 0.32 & 6.70 \\
\hline 1 & 2.52 & 0.79 & 0.74 & 0.28 & 0.80 & 4.60 \\
\hline 5 & 2.06 & 0.82 & 0.85 & 0.22 & 0.83 & 4.56 \\
\hline 12 & 1.84 & 0.84 & 0.99 & 0.16 & 0.84 & 4.52 \\
\hline 21 & 1.72 & 0.86 & 1.14 & 0.21 & 0.88 & 4.47 \\
\hline 30 & 1.78 & 0.87 & 1.21 & 0.17 & 0.92 & 4.42 \\
\hline \multicolumn{7}{|c|}{ Batch 2-Yogurt produced using immobilized L. casei and L. bulgaricus removed after fermentation $\left(I R_{2}\right)$} \\
\hline 0 & 5.00 & nd & nd & 0.16 & 0.32 & 6.70 \\
\hline 1 & 2.07 & 0.76 & 0.91 & 0.26 & 0.79 & 4.62 \\
\hline 5 & 2.05 & 0.77 & 0.91 & 0.10 & 0.82 & 4.56 \\
\hline 12 & 1.92 & 0.79 & 0.94 & 0.21 & 0.84 & 4.52 \\
\hline 21 & 1.84 & 0.83 & 0.98 & 0.14 & 0.87 & 4.47 \\
\hline 30 & 1.82 & 0.84 & 1.08 & 0.10 & 0.89 & 4.45 \\
\hline \multicolumn{7}{|c|}{ Batch 3-Yogurt produced using immobilized L. casei and L. bulgaricus removed after fermentation (IR $\left.{ }_{3}\right)$} \\
\hline 0 & 5.00 & nd & nd & 0.16 & 0.32 & 6.70 \\
\hline 1 & 2.16 & 0.72 & 0.91 & 0.27 & 0.79 & 4.60 \\
\hline 5 & 2.14 & 0.72 & 0.93 & 0.23 & 0.80 & 4.60 \\
\hline 12 & 2.08 & 0.74 & 0.94 & 0.12 & 0.82 & 4.56 \\
\hline 21 & 1.96 & 0.80 & 0.95 & 0.16 & 0.83 & 4.52 \\
\hline 30 & 1.95 & 0.81 & 0.96 & 0.08 & 0.84 & 4.50 \\
\hline \multicolumn{7}{|c|}{ Batch 4-Yogurt produced using immobilized L. casei and L. bulgaricus removed after fermentation $\left(I_{4}\right)$} \\
\hline 0 & 5.00 & nd & nd & 0.16 & 0.32 & 6.70 \\
\hline 1 & 2.57 & 0.61 & 0.81 & 0.26 & 0.80 & 4.60 \\
\hline 5 & 2.56 & 0.61 & 0.83 & 0.27 & 0.81 & 4.60 \\
\hline 12 & 2.44 & 0.64 & 0.87 & 0.28 & 0.82 & 4.59 \\
\hline 21 & 2.42 & 0.66 & 0.92 & 0.16 & 0.82 & 4.59 \\
\hline 30 & 2.40 & 0.67 & 0.92 & 0.12 & 0.83 & 4.58 \\
\hline \multicolumn{7}{|c|}{ Batch 5-Yogurt produced using immobilized L. casei and L. bulgaricus removed after fermentation (IR $\left.R_{5}\right)$} \\
\hline 0 & 5.00 & nd & nd & 0.16 & 0.32 & 6.70 \\
\hline 1 & 3.16 & 0.56 & 0.75 & 0.25 & 0.78 & 4.61 \\
\hline 5 & 3.09 & 0.57 & 0.77 & 0.23 & 0.79 & 4.60 \\
\hline 12 & 2.96 & 0.62 & 0.79 & 0.19 & 0.80 & 4.60 \\
\hline 21 & 2.89 & 0.65 & 0.84 & 0.04 & 0.80 & 4.60 \\
\hline 30 & 2.87 & 0.65 & 0.87 & nd & 0.81 & 4.60 \\
\hline \multicolumn{7}{|c|}{ Yogurt produced using immobilized L. casei and L. bulgaricus maintained in yogurt after fermentation (IM) } \\
\hline 0 & 5.00 & nd & nd & 0.16 & 0.32 & 6.70 \\
\hline 1 & 2.12 & 0.84 & 0.95 & 0.24 & 0.82 & 4.58 \\
\hline 5 & 1.22 & 0.87 & 1.07 & 0.26 & 0.90 & 4.46 \\
\hline 12 & 1.01 & 0.92 & 1.11 & 0.27 & 0.92 & 4.40 \\
\hline 21 & 0.10 & 0.93 & 1.26 & 0.21 & 0.97 & 4.36 \\
\hline 30 & $\operatorname{Tr}$ & 0.87 & 1.30 & 0.16 & 1.03 & 4.35 \\
\hline
\end{tabular}

nd: not detected; Tr: traces, $<0.00$; Standard deviations: lactose $\leq 0.05$, galactose $\leq 0.003$, lactic acid $\leq 0.05$, citric acid $\leq 0.004$, titratable acidity $\leq 0.05, p H \pm 0.38$.

Lactose concentration was determined by HPLC on a Shimadzu chromatograph (Kyoto, Japan) with a SCR-101N stainless steel column, a LC-9A pump, a CTO-10A oven at $60^{\circ} \mathrm{C}$, and a RID-6A refractive index detector. Ultrapure water obtained using a Milli-Q water purifier system (resistivity $18.2 \mathrm{M} \Omega \times \mathrm{cm}$ at $25^{\circ} \mathrm{C}$ ) was used as the mobile phase at a flow rate of $0.8 \mathrm{~mL} \mathrm{~min}^{-1}$, and 1-butanol $(0.1 \% \mathrm{v} / \mathrm{v})$ was used as the internal standard. Sample dilution was $1 \% \mathrm{v} / \mathrm{v}$, and the injection volume was $40 \mathrm{~mL}$. Lactose concentrations were calculated using standard curves.
Organic acids were analyzed on a Jasco LC-2000 Series HPLC system (Jasco Inc., Japan) equipped with a size-exclusion organic acid analysis column (Aminex HPX-87H, $300 \times 7.8 \mathrm{~mm}$ i.d., $9 \mu \mathrm{m}$ particle size, Bio-rad, France) fitted to a CO-2060 PLUS column oven, a PU-2089 pump, an AS 2050 PLUS autosampler, and a MD-2018 Photodiode array detector operated at $210 \mathrm{~nm}$. Isocratic separation was performed at $50^{\circ} \mathrm{C}$ using $0.008 \mathrm{~N} \mathrm{H}_{2} \mathrm{SO}_{4}$ as the mobile phase at a flow rate of $0.6 \mathrm{~mL} \mathrm{~min}^{-1}$. The detector signals were recorded and analyzed by ChromNav software. For quantitative analysis, stan- 
dard solutions of acids (Sigma-Aldrich Ltd) were prepared in pure water (Milli-Q, Merk) at various concentrations.

\subsection{SPME GC/MS analysis of volatile compounds}

The composition of volatile compounds in yogurt samples was determined by solid-phase microextraction (SPME) gas chromatography/mass spectrometry (GC/MS). Samples of $7 \mathrm{~g}$ were collected on the first day of storage. For the analysis, a $20-\mathrm{mL}$ headspace vial was filled up to $3 / 4$ of its volume with the yogurt sample ( $7 \mathrm{~g}$ ) that was mixed with $3 \mathrm{~g}$ of salt. Each vial was fitted with a Teflonlined septum sealed with an aluminum crimp seal, and then the SPME syringe needle (bearing a 2-cm fiber coated with $50 / 30 \mathrm{~mm}$ Divinylbenzene/Carboxen on poly-dimethyl-siloxane bonded to a flexible fused silica core; Supelco, Bellefonte, PA, USA) was inserted through the septum. Each vial was heated in a water bath at $60^{\circ} \mathrm{C}$ for $3 \mathrm{~min}$ before the fiber was exposed to the headspace for $45 \mathrm{~min}$ at the same temperature. A crucial step is that the length of the fiber in the headspace must be maintained constant.

The absorbed volatile compounds were analyzed by GC/MS on a Shimadzu GC-17A gas chromatograph coupled to a Shimadzu MS QP5050 mass spectrometer as described previously by Kourkoutas et al. with small modifications [10]. The compounds were identified by mass spectra from NIST107, NIST21, and SZTERP libraries and by determining the Kovats retention indices (KI) and comparing with those reported in the literature $[5,8,20]$ (identical with reference compound: RF; in agreement with literature: RI) (Table 2). The KIs were determined by injecting a standard mixture containing the homologous series of normal alkanes $\left(C_{1}-C_{21}\right)$ in pure hexane under exactly the same experimental conditions. The volatile compounds were quantified as described previously by Dimitrellou et al. with small modifications [21]. Briefly, methyl octanoate (Sigma-Aldrich, Poole, UK) diluted in pure ethanol was used as the internal standard at a concentration of $125 \mu \mathrm{g} \mathrm{kg}^{-1}$. The volatile compounds were quantified by dividing the peak areas of each previously identified compound by the peak area of the internal standard and multiplying this ratio by the initial concentration of the internal standard (expressed as $\mu \mathrm{g} \mathrm{kg}^{-1}$ ). Each determination was performed in triplicate (standard deviation for all values was approximately $\pm 5 \%$ ).

\subsection{Sensory evaluation}

Sensory evaluation was performed by 20 laboratory members previously trained using locally approved protocols (between 20 and 40 years of age, equal distribution between male and female). Samples $(\sim 30 \mathrm{~g})$ of yogurts (C, F, IM, and $\left.\mathrm{IR}_{1}\right)$ were presented 1 day after production (first day of storage). Yogurt samples were randomly coded and served at $4{ }^{\circ} \mathrm{C}$. The samples were scored from 0 (lowest) to 10 (highest) for sensory attributes (Table 3 ). The sensory attributes considered were flavor (sweet, acid, and cereal), appearance, texture, odor, and overall acceptability. Panelists used water to clean their palates between samples and were unaware of the samples they tasted (samples were labeled with tree-number codes for identification). Each panelist received two samples for each yogurt and three subsequently independent experiments were conducted.

\subsection{Scanning electron microscopy}

Samples of the two immobilized biocatalysts were examined by SEM to observe the immobilization of $L$. casei and L. bulgaricus cells. For comparison reasons, samples of DWB were also observed. The samples of each biocatalyst were washed separately with sterile Ringer's solution and were then freeze-dried at $5 \times 10^{-3}$ bar and at $-45^{\circ} \mathrm{C}$ in a Freeze Drying System, Freezone 4.5 (Labconco, Kansas
City, Missouri, USA) [9] for $72 \mathrm{~h}$. All dried samples were coated with gold in a Balzers SCD 004 Sputter coater (Bal-Tec, Schalksmuhle, Germany) for 2 min and examined in a JSM-6300 scanning electron microscope (JEOL, Tokyo, Japan).

\subsection{Statistical analysis}

All fermentations were conducted in triplicate, and the mean values are presented (standard deviation for all values was approximately $\pm 5 \%$ in most cases). The significance of differences in the means of various groups was checked by one-way analysis of variance at $5 \%$ level of significance.

\section{Results and discussion}

Yogurt is widely recognized by both science and industry as a suitable dairy product for the delivery of probiotics. Among probiotic species, $L$. casei has been extensively used in fermented products $[5,8,9,20,22]$ because of its excellent technological properties and potential health benefits. Moreover, the ATCC 393 strain can survive the harsh conditions of the gastrointestinal tract (GI) as shown by in vitro screening of survival in simulated GI conditions [7] and in vivo studies [23]. The common method for providing a probiotic culture to the dairy industry is in a dry state, but drying may cause irreversible injuries to the bacterial cells [24]. In the present study, a prebiotic cereal by-product was evaluated as an immobilization carrier to protect $L$. casei during drying and freezing to produce a ready-to-use dry biocatalyst for probiotic yogurt production. Cereals and their by-products, such as wheat bran, possibly stimulate the growth and survival of LAB strains during fermentation because they contain prebiotic compounds [25]. Therefore, we used wheat bran as a low-cost carrier for the immobilization of $L$. casei and L. bulgaricus cells for probiotic yogurt production. Moreover, because the conventional yogurt starter $S$. thermophilus can reduce the probiotic potential of $L$. casei [26], it was used in this study only as a control sample for the production of classic yogurt.

\subsection{Yogurt production and microbiological analysis}

The immobilized biocatalysts were tested for live cell numbers, and cell immobilization was observed by SEM. The $L$. casei and $L$. bulgaricus cells immobilized on DWB are presented in Fig. 1(a-c) and Fig. 2(a-c), respectively. Fig. 3(a-d) illustrates the surface of plain DWB. Figs. 4 and 5 show changes of yogurts cell counts during 30 days of storage $\left(4^{\circ} \mathrm{C}\right)$. The $S$. thermophilus counts declined during storage as reported in several other studies on commercial starter cultures $[11,27]$. The L. bulgaricus cell counts also showed a considerable continuous decrease during storage in all yogurt samples. The population of $L$. bulgaricus in commercial yogurts is known to be affected by the presence of $S$. thermophilus [28]. In yogurt samples produced using L. casei and L. bulgaricus (F, IM, and IR samples), both microbial populations decreased until the day 30. Yogurts produced using the immobilized biocatalysts (IM and IR) had significantly higher populations of these microorganisms in the final product $(\mathrm{P}<0.05)$ than yogurts produced using free cells $(F)$. This may be because the prebiotic effect of wheat bran increased their population during fermentation. This is in agreement with the results of previous studies regarding the prebiotic and protective effect of cereals and cereal extracts on Lactobacillus sp. during fermentation and storage $[8,9,12]$. In the case of free $L$. casei cells, although the number of viable cells decreased, the number was maintained within the recommended levels for probiotics $\left(>10^{7} \mathrm{cfu}^{-1}\right)$ until day 30 of storage.

In the case of the successive fermentation batches using the same biocatalyst (IR) (Fig. 5), the initial lactobacilli count appeared lower as the biocatalyst was moved from one batch to the other. The 
Table 2

Identification of headspace volatile compounds $\left(\mu \mathrm{g} \mathrm{kg}^{-1}\right)$ by SPME GC/MS of yogurt samples on the first day of storage at $4{ }^{\circ} \mathrm{C}$.

\begin{tabular}{|c|c|c|c|c|c|c|c|c|c|c|}
\hline \multirow[t]{2}{*}{ KI } & \multirow[t]{2}{*}{ Compound name } & \multirow[t]{2}{*}{ *Id. Method } & \multicolumn{8}{|c|}{ Yogurt sample } \\
\hline & & & $\mathrm{C}$ & $\mathrm{F}$ & $\mathrm{IR}_{1}$ & $\mathrm{IR}_{2}$ & $\mathrm{IR}_{3}$ & $\mathrm{IR}_{4}$ & $\mathrm{IR}_{5}$ & IM \\
\hline & Esters & & & & & & & & & \\
\hline 1039 & Ethyl butanoate & $\mathrm{KI}, \mathrm{RF}$ & nd & $8.8 \pm 0.3$ & $8.2 \pm 0.3$ & $7.9 \pm 0.2$ & $6.4 \pm 0.2$ & $7.2 \pm 0.1$ & $6.6 \pm 0.1$ & $9.6 \pm 0.3$ \\
\hline 1250 & Ethyl hexanoate & $\mathrm{KI}, \mathrm{RF}$ & nd & $\mathrm{Tr}$ & $\mathrm{Tr}$ & $\mathrm{Tr}$ & nd & nd & nd & $1.6 \pm 0.1$ \\
\hline 1420 & Ethyl octanoate & $\mathrm{KI}, \mathrm{RF}$ & nd & $\operatorname{Tr}$ & $2.0 \pm 0.1$ & $1.7 \pm 0.1$ & $1.9 \pm 0.1$ & $1.1 \pm 0.1$ & $\operatorname{Tr}$ & $2.1 \pm 0.1$ \\
\hline 1634 & Ethyl decanoate & $\mathrm{KI}, \mathrm{RF}$ & $\operatorname{Tr}$ & $1.6 \pm 0.1$ & $2.2 \pm 0.1$ & $1.2 \pm 0.1$ & $\operatorname{Tr}$ & $\operatorname{Tr}$ & nd & $2.9 \pm 0.2$ \\
\hline \multirow[t]{2}{*}{1814} & $\begin{array}{l}\text { 2-Phenylethyl } \\
\text { acetate }\end{array}$ & $\mathrm{KI}, \mathrm{RF}$ & $2.4 \pm 0.2$ & $6.4 \pm 0.3$ & $7.2 \pm 0.3$ & $7.0 \pm 0.3$ & $6.9 \pm 0.2$ & $6.6 \pm 0.2$ & $6.7 \pm 0.2$ & $7.9 \pm 0.3$ \\
\hline & Total & & 2.4 & 16.8 & 19.6 & 17.8 & 15.2 & 14.9 & 13.3 & 24.1 \\
\hline \multicolumn{11}{|c|}{ Organic acids } \\
\hline 1627 & Pentanoic acid & $\mathrm{KI}, \mathrm{RF}$ & $9.3 \pm 0.3$ & $7.1 \pm 0.3$ & $6.5 \pm 0.3$ & $5.3 \pm 0.2$ & $1.7 \pm 0.1$ & $\operatorname{Tr}$ & nd & 24.1 \\
\hline 1660 & $\begin{array}{l}\text { 3-Methyl } \\
\text { butanoic acid }\end{array}$ & $\mathrm{KI}, \mathrm{RI}$ & $22 \pm 2$ & $17 \pm 2$ & $11 \pm 1$ & $12 \pm 1$ & $13 \pm 1$ & $13 \pm 1$ & $14 \pm 1$ & $10.2 \pm 1$ \\
\hline 1793 & $\begin{array}{l}\text { 4-Methyl } \\
\text { pentanoic acid }\end{array}$ & $\mathrm{KI}, \mathrm{RI}$ & nd & nd & $3.8 \pm 0.2$ & nd & nd & nd & nd & $5.6 \pm 0.2$ \\
\hline 1844 & Hexanoic acid & $\mathrm{KI}, \mathrm{RF}$ & $55 \pm 3$ & $84 \pm 4$ & $93 \pm 4$ & $78 \pm 3$ & $26 \pm 2$ & $14 \pm 1$ & $\operatorname{Tr}$ & $116 \pm 7$ \\
\hline 1970 & Heptanoic acid & $\mathrm{KI}, \mathrm{RF}$ & $6.9 \pm 0.3$ & $5.5 \pm 0.2$ & $5.7 \pm 0.2$ & $2.5 \pm 0.1$ & $1.2 \pm 0.1$ & $1.1 \pm 0.1$ & $\operatorname{Tr}$ & $6.2 \pm 0.2$ \\
\hline 2070 & Octanoic acid & $\mathrm{KI}, \mathrm{RF}$ & $136 \pm 10$ & $254 \pm 13$ & $282 \pm 14$ & $246 \pm 13$ & $258 \pm 13$ & $274 \pm 14$ & $222 \pm 12$ & $308 \pm 16$ \\
\hline 2211 & Nonanoic acid & $\mathrm{KI}, \mathrm{RF}$ & nd & nd & $3.7 \pm 0.2$ & $2.4 \pm 0.2$ & $\operatorname{Tr}$ & nd & nd & $4.2 \pm 0.3$ \\
\hline 2300 & n-Decanoic acid & $\mathrm{KI}, \mathrm{RF}$ & $36 \pm 2$ & $30 \pm 2$ & $42 \pm 2$ & $44 \pm 2$ & $33 \pm 2$ & $27 \pm 2$ & $21 \pm 2$ & $60 \pm 3$ \\
\hline \multirow{2}{*}{2484} & Dodecanoic acid & $\mathrm{KI}, \mathrm{RF}$ & $25 \pm 2$ & $27 \pm 2$ & $37 \pm 2$ & $42 \pm 2$ & $46 \pm 2$ & $58 \pm 3$ & $63 \pm 3$ & $34 \pm 2$ \\
\hline & Total & & 390.2 & 424.6 & 484.7 & 432.2 & 378.9 & 387.1 & 320.0 & 568.3 \\
\hline \multicolumn{11}{|c|}{ Alcohols } \\
\hline 929 & Ethanol & $\mathrm{KI}, \mathrm{RF}$ & $>10,000$ & $»$ & $"$ & $»$ & $»$ & $»$ & $"$ & $"$ \\
\hline 1161 & 1-Butanol & $\mathrm{KI}, \mathrm{RF}$ & $2.4 \pm 0.1$ & nd & nd & nd & nd & nd & nd & nd \\
\hline 1215 & $\begin{array}{l}\text { 3-Methyl- } \\
\text { 1-butanol }\end{array}$ & $\mathrm{KI}, \mathrm{RI}$ & nd & $3.3 \pm 0.1$ & $3.1 \pm 0.1$ & $3.4 \pm 0.1$ & $\operatorname{Tr}$ & $\operatorname{Tr}$ & $\operatorname{Tr}$ & $3.2 \pm 0.1$ \\
\hline 1350 & 1-Hexanol & $\mathrm{KI}, \mathrm{RF}$ & $1.5 \pm 0.1$ & nd & nd & nd & nd & nd & nd & nd \\
\hline 1564 & 1-Octanol & $\mathrm{KI}, \mathrm{RF}$ & $2.8 \pm 0.1$ & nd & nd & nd & nd & nd & nd & nd \\
\hline \multirow[t]{2}{*}{1913} & Phenyl ethanol & KI,RI & nd & nd & $1.7 \pm 0.1$ & $\operatorname{Tr}$ & nd & nd & nd & $\operatorname{Tr}$ \\
\hline & Total & & 6.7 & 3.3 & 4.8 & 3.4 & - & - & - & 3.2 \\
\hline \multicolumn{11}{|c|}{ Carbonyl compounds } \\
\hline 823 & Acetone & $\mathrm{KI}, \mathrm{RF}$ & $1.1 \pm 0.1$ & $0.8 \pm 0.1$ & $1.2 \pm 0.1$ & $1.1 \pm 0.1$ & $0.7 \pm 0.1$ & $\operatorname{Tr}$ & $\operatorname{Tr}$ & $1.0 \pm 0.1$ \\
\hline 978 & 2,3-Butanedion & $\mathrm{KI}, \mathrm{RF}$ & $7 \pm 1$ & $13 \pm 1$ & $14 \pm 1$ & $6 \pm 1$ & $11 \pm 1$ & $14 \pm 1$ & $16 \pm 1$ & $12 \pm 2$ \\
\hline 1057 & $\begin{array}{l}\text { 2,3- } \\
\text { Pentanedione }\end{array}$ & $\mathrm{KI}, \mathrm{RF}$ & $4.7 \pm 0.3$ & $3.4 \pm 0.2$ & $6.8 \pm 0.3$ & $2.2 \pm 0.1$ & $6.4 \pm 0.3$ & $2.6 \pm 0.1$ & $1.7 \pm 0.1$ & $2.6 \pm 0.2$ \\
\hline 1203 & 2-Heptanone & $\mathrm{KI}, \mathrm{RF}$ & $42 \pm 2$ & $69 \pm 4$ & $84 \pm 4$ & $85 \pm 4$ & $84 \pm 4$ & $83 \pm 4$ & $86 \pm 4$ & $91 \pm 4$ \\
\hline 1298 & $\begin{array}{l}\text { 3-Hydroxy } \\
\text { 2-butanone } \\
\text { (acetoin) }\end{array}$ & $\mathrm{KI}, \mathrm{RI}$ & $79 \pm 4$ & $86 \pm 4$ & $84 \pm 4$ & $72 \pm 4$ & $68 \pm 4$ & $66 \pm 4$ & $64 \pm 4$ & $89 \pm 4$ \\
\hline 1392 & Nonanal & $\mathrm{KI}, \mathrm{RF}$ & nd & $47 \pm 3$ & $57 \pm 3$ & $24 \pm 2$ & nd & nd & nd & $63 \pm 4$ \\
\hline 1376 & 2-Nonanone & $\mathrm{KI}, \mathrm{RI}$ & $73 \pm 6$ & $77 \pm 6$ & $76 \pm 6$ & $63 \pm 6$ & $72 \pm 6$ & $77 \pm 6$ & $73 \pm 6$ & $74 \pm 6$ \\
\hline \multirow[t]{2}{*}{1508} & Benzaldehyde & $\mathrm{KI}, \mathrm{RF}$ & nd & $2.1 \pm 0.1$ & $2.7 \pm 0.1$ & $3.1 \pm 0.1$ & $4.4 \pm 0.1$ & $\operatorname{Tr}$ & $2.8 \pm 0.1$ & $\operatorname{Tr}$ \\
\hline & Total & & 206.8 & 298.3 & 325.7 & 256.4 & 246.5 & 242.6 & 240.5 & 332.6 \\
\hline \multicolumn{11}{|c|}{ Miscellaneous compounds } \\
\hline 1034 & Toluene & KI,RI & nd & $39 \pm 2$ & $36 \pm 2$ & $37 \pm 2$ & $47 \pm 3$ & $32 \pm 2$ & $24 \pm 2$ & $10 \pm 1$ \\
\hline 1261 & D-Limonene & $\mathrm{KI}, \mathrm{RF}$ & nd & $1.8 \pm 0.1$ & $4.5 \pm 0.2$ & $4.8 \pm 0.2$ & $5.8 \pm 0.3$ & $5.7 \pm 0.2$ & $3.5 \pm 0.2$ & 2.6 \\
\hline \multirow[t]{3}{*}{1246} & 2-Pentyl furan & $\mathrm{KI}, \mathrm{RF}$ & nd & $2.8 \pm 0.1$ & $3.6 \pm 0.1$ & $2.0 \pm 0.1$ & $1.1 \pm 0.1$ & $\operatorname{Tr}$ & $\operatorname{Tr}$ & $3.1 \pm 0.1$ \\
\hline & Total & & - & 43.6 & 44.1 & 43.8 & 53.9 & 37.7 & 27.5 & 15.7 \\
\hline & $\begin{array}{l}\text { Total volatile } \\
\text { compounds }\end{array}$ & & 606.1 & 786.6 & 878.9 & 753.6 & 694.6 & 682.3 & 601.3 & 943.9 \\
\hline
\end{tabular}

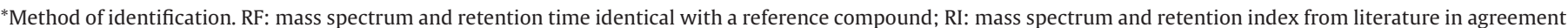

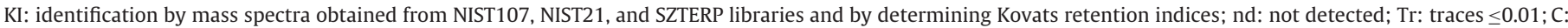

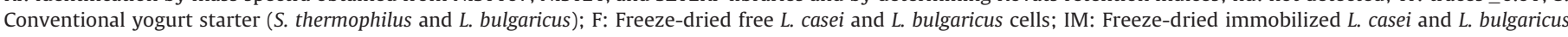

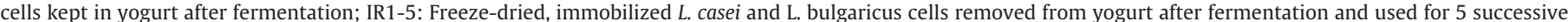
fermentation batches.

biocatalyst lost its activity after the fifth batch. Moreover, microbiological analysis of the biocatalysts showed the absence of viable cells of $L$. bulgaricus (data not shown).

\subsection{Viability of free and immobilized cells in simulated gastric juice}

The viability of the probiotic $L$. casei in simulated gastric acid ( $\mathrm{pH}$ 3.0) was assessed both in the form of a biocatalyst (free or immobilized cells) and in the fermented yogurt, (Fig. 6) as one of the most important factors for loss of cell viability is low pH [29]. A continuous decrease in cell viability was observed in all samples.
Incubation for $2 \mathrm{~h}$ in the simulated gastric juice led to more cell viability loss in free cells (S1) than in immobilized cells (S2). Similarly, in the yogurt samples (WI), immobilization enhanced the viability of $L$. casei under simulated gastric juice conditions (initial $9.94 \log \mathrm{cfu} \mathrm{g}^{-1}$; final $9.27 \log \mathrm{cfu}^{-1}$ ) compared to the significant decrease observed in yogurt samples with free cells $(F)$ (initial $9.50 \log \mathrm{cfu} \mathrm{g}^{-1}$; final $8.22 \log \mathrm{cfu} \mathrm{g}^{-1}$ ). Therefore, immobilization on wheat bran can be a useful technique to enhance the viability of probiotic Lactobacillus sp., which must survive in high numbers during yogurt fermentation, storage, and passage through the GI tract. 
Table 3

Sensory evaluation of the produced yogurt samples after the first day of storage at $4{ }^{\circ} \mathrm{C}$

\begin{tabular}{lllll}
\hline \multirow{2}{*}{ Sensory attribute } & \multicolumn{4}{l}{ Yogurt sample } \\
\cline { 2 - 5 } & $\mathrm{C}$ & $\mathrm{F}$ & $\mathrm{IR}_{1}$ & $\mathrm{IM}$ \\
\hline Acidic flavor & 6.7 & 7.2 & 8.0 & 8.1 \\
Sweet flavor & 5.4 & 6.7 & 6.7 & 6.8 \\
Cereal flavor & 0.0 & 0.0 & 6.2 & 8.9 \\
Texture & 9.1 & 8.7 & 9.0 & 8.6 \\
Odor & 9.7 & 9.7 & 9.8 & 9.7 \\
Appearance & 8.7 & 8.8 & 8.9 & 8.7 \\
Overall acceptance & 8.6 & 8.8 & 8.9 & 8.8 \\
\hline
\end{tabular}

Data are the means of three independent experiments \pm 0.3 standard deviation, twice analyzed. Sensory attributes were scored by using a scale of 0-10.

\subsection{Physicochemical changes during storage}

The physicochemical characteristics of the produced yogurts after 30 days of storage are presented in Table 1 . A pH decrease during storage was detected in all samples as a result of postacidification due to the residual activity of microorganisms that continuously enriched yogurt with lactic acid. The lowest $\mathrm{pH}(4.3)$ was observed in yogurt produced using immobilized cells (IM) on day 30 of storage. Overall, no significant variations $(P>0.05)$ in $\mathrm{pH}$ values were observed among the different samples during the first 5 days of storage. Moreover, yogurt produced using commercial culture $(C)$ retained a significantly higher $(\mathrm{P}<0.05) \mathrm{pH}$ than yogurt produced using the free probiotic culture $(\mathrm{F})$ during the total storage period. Yogurt $\mathrm{pH}$ values of 4.1-4.2 (initial pH 4.7-4.8) were also reported by other researchers [33] in samples fermented with S. thermophilus and L. acidophilus/bifidobacteria or L. casei after 35 days of refrigerated storage $\left(4^{\circ} \mathrm{C}\right)$. Postacidification depends on the type of cultures used and the remaining viable cell counts in each product. Therefore, the yogurt with higher number of remaining immobilized lactobacilli (IM) showed a significantly higher $\mathrm{pH}$ decrease from day 12 to 30 of storage than the other yogurt samples, a result that can be attributed to the higher lactic acid production in yogurt by the embodied biocatalyst. Compared to free cells, lower $\mathrm{pH}$ values may also be due to the growth of the immobilized cells at higher numbers and the protective action of wheat bran against the inhibitive effect of the increasing lactic acid concentration [8].

Acid production also depends on the ability of lactobacilli to ferment carbohydrates in milk. In the present study, lactose was continuously consumed during storage in all yogurt samples, whereas there was a simultaneous increase in lactic acid production and acidity, as shown in various other studies of milk fermentation $[5,8,30,31]$.

The acidity (0.80-1.03\%) of yogurts produced using immobilized L. casei cells that remained in the product after fermentation (IM) was significantly lesser $(\mathrm{P}<0.05)$ than that of yogurt produced using the commercial culture (C) $(0.82-0.91 \%)$. For yogurts produced using the immobilized biocatalyst that was removed at the end of fermentation (IR), a significant decline $(P<0.05)$ was observed in the total acidity form batch 1 to batch 5 because of the decreased viability of the biocatalyst (Fig. 5). No major differences $(P>0.05)$ in acidity were observed among yogurts produced using commercial culture, free probiotic cells, or the immobilized biocatalyst that was removed from yogurt (first batch of yogurt, $I_{1}$ ). In general, the acidity levels $(0.78-1.03 \%)$ of all the produced yogurts were similar to those reported in the literature for commercial yogurt products and yogurt products with added probiotic culture $[5,30]$.

Lactic acid, quantitatively the most important acid found in LAB fermentations, imparts a mild acidic taste (threshold $20 \mathrm{mg} \mathrm{L}^{-1}$ in water) in fermented milks, which was described as "tart" or "acrid" by Hartwig and McDaniel [32]. Lactic acid content significantly $(\mathrm{P}<0.05)$ increased in all samples during storage, resulting
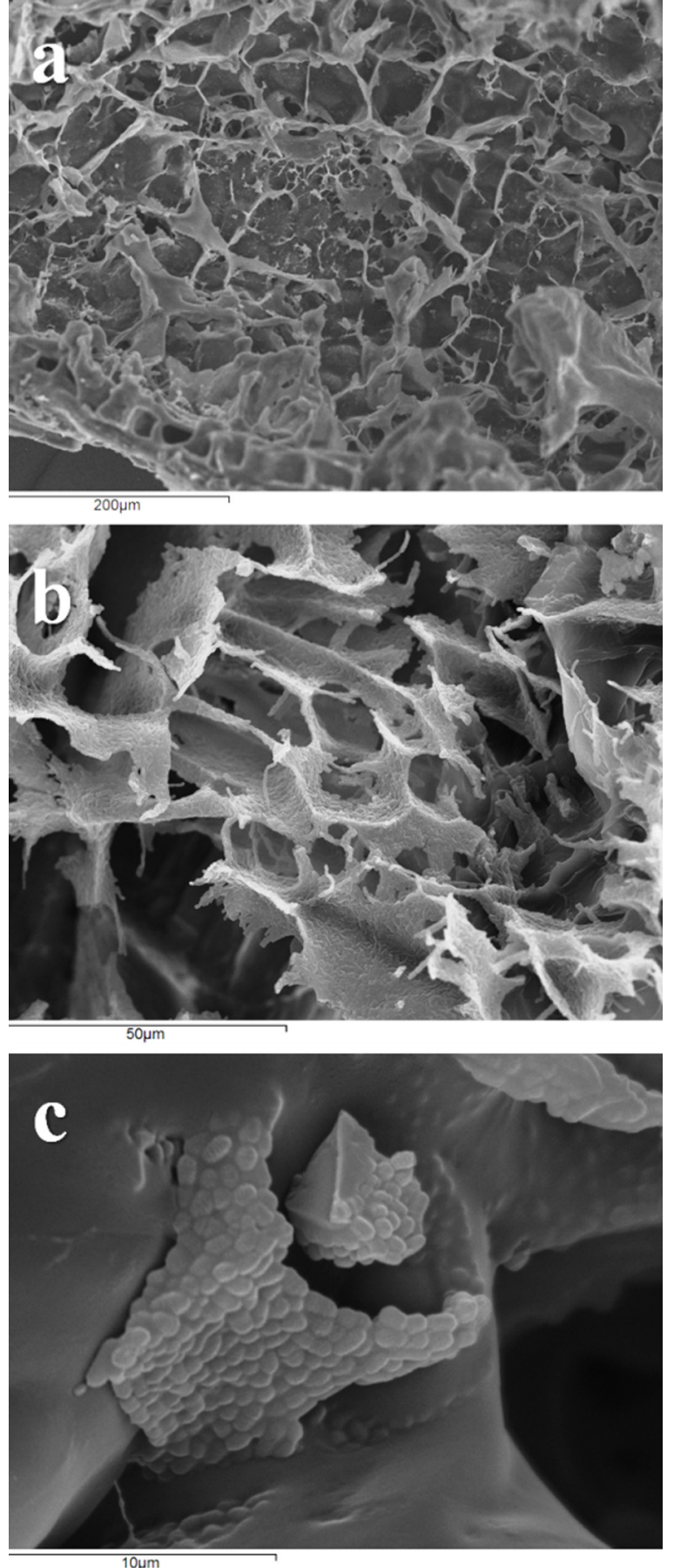

Fig. 1. SEM images of $L$. casei ATCC 393 cells immobilized on DWB at different magnifications $[(a) \times 200$; (b) $\times 1000$; (c) $\times 5000]$.

in a characteristic acid taste as indicated by the sensory analysis (Table 3). As expected, lactic acid was significantly higher in the fermented yogurts where higher LAB viabilities were observed. Smaller amounts of citric acid were also found, at concentrations following an irregular pattern during storage, which was in agreement with that reported in other studies in the literature $[33,34]$.

Lactose content was reduced by approximately $40-60 \%$ in all yogurt samples except IM (Table 1). In IM, a significant difference $(P>0.05)$ was observed in the lactose content, with almost all the lactose consumed because of the significantly higher LAB viability in the IM yogurts during storage. Galactose, however, showed a continuous increase in all yogurt samples, which corresponded to 

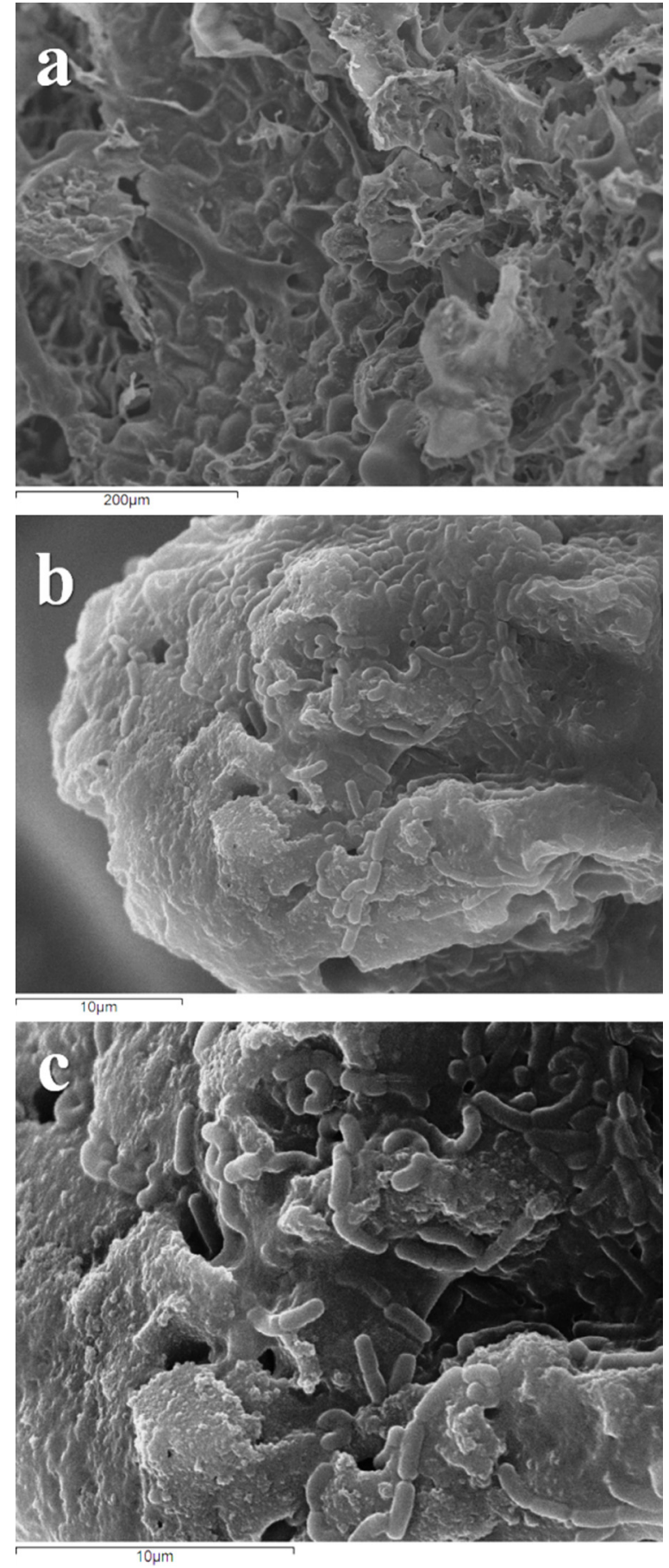

Fig. 2. SEM images of immobilized $L$. bulgaricus DSM 20081 cells on DWB at different magnifications [(a) $\times 200$; (b) $\times 5000$; (c) $\times 5000]$.

the lactose consumption, with significant $(\mathrm{P}>0.05)$ differences in yogurts with lower lactose concentrations.

\subsection{Sensory evaluation of yogurts}

All the produced yogurts were assessed for odor, flavor, texture, and overall rating by previously trained laboratory members (Table 3). All yogurts were characterized by a sour acid taste, which is common for fermented milk products because of sugar metabolism into organic acids by LAB. The increase in sourness usually coincides with a general decrease in sweetness, a result which was not observed in this study. Yogurt samples with higher lactic acid production (Table 1 ) were not characterized as highly acidic (IR and $\mathrm{IM}_{1}$ ), whereas the control yogurt samples (C) received the highest scores for acidity (7.4). A possible explanation was given by Salmerón, Thomas and Pandiella [35] who proposed $\mathrm{pH}$ to be an important factor influencing the final acceptance of a novel beverage; $\mathrm{pH}$ values higher than 3.5 were correlated with higher acceptance of a beverage. This result may be attributed to the enzymatic release of sugar moieties from polysaccharides that again exceed the sugar consumption by LAB, leading the sweet taste to increase again [36].

In general, all yogurts were favorably evaluated but significant differences were observed between yogurts produced using immobilized cells and those produced using the commercial yogurt culture (Table 3). According to the evaluator comments, wheat provided special cereal flavor to IM and IR yogurts, possibly due to compounds extracted to yogurt from wheat bran during fermentation. Moreover, yogurts produced using the $L$. casei and $L$. bulgaricus cultures (F, IM, and IR) were characterized for their sweet flavor and pleasant coherent texture.

\subsection{Volatile compounds in yogurts}

The results of the SPME GC/MS analysis of yogurt samples (after the first day of production) are presented in Table 2. The flavor of yogurts depends on particular key components that give them a characteristic sour sweet or in specific occasions as in the present study, a cereal taste to the final product (Table 3). From a quantitative point of view, the probiotic culture significantly affected $(\mathrm{P}<0.05)$ the concentrations of all the volatile compounds. A total of five esters (24.1 $\mu \mathrm{g} \mathrm{kg}-1)$ were detected in the IM yogurts, which also received the highest scores by the evaluators, indicating a characteristic cereal flavor and sweet-sour taste as described above. In the control yogurts (C), only two esters $(2.4 \mu \mathrm{g} \mathrm{kg}-1)$ were detected, whereas in yogurts produced using free cells $(F)$, the same five esters as in the IM samples were detected but at significantly lower concentrations ( $16.8 \mu \mathrm{g} \mathrm{kg}-1$ ). Sweetness was higher in the yogurts produced using the probiotic culture (F, IM, and IR) (Table 3), but it was more intense in those produced using the immobilized biocatalysts than free cells. This sweet flavor in yogurts containing the probiotic $L$. casei strain may be a result of the presence of some esters such as ethyl butanoate (9.6-6.6 $\mu \mathrm{g} \mathrm{kg}-1)$.Only in the IM samples, evaluators commented that they detected a special sweet-fruity flavor, which may be explained by the presence of ethyl hexanoate or ethyl octanoate, which were detected in notable amounts only in the IM yogurts. According to Pico, Bernal and Gómez [37], these esters can give a sweet, fruity, or pineapple odor to the product.

Short-chain free fatty acids (hexanoic, heptanoic, and octanoic) were detected in all the yogurts, whereas some long-chain fatty acids (nonanoic, dodecanoic, and n-decanoic) were detected but not in all samples. This result was also assessed by Beshkova, Simova, Frengova and Simov [38] who observed an increase in volatile short-chain free fatty acids (C4-C8), which was related to the increased activity of $L$. bulgaricus. Similarly, in this case, high metabolic activity of $L$. bulgaricus during fermentation and storage led to higher concentrations of short-chain fatty acids.

Among the detected alcohols, ethanol was found in all samples. Ethanol does not contribute directly to the overall flavor of dairy products unless there is extensive yeast contamination or heterofermentative metabolism, which would turn ethanol to a major by-product. Ethanol may also be detected in fresh milk as a mild flavor because of lactose metabolism by milk microflora [39].

Regarding carbonyl compounds, the strongest effects on yogurt aroma are usually imparted by 2,3-butanedione (diacetyl) and 2,3pentanedione [38]. A butterscotch-like aroma was observed in the IM yogurts where diacetyl was detected at higher concentrations. 

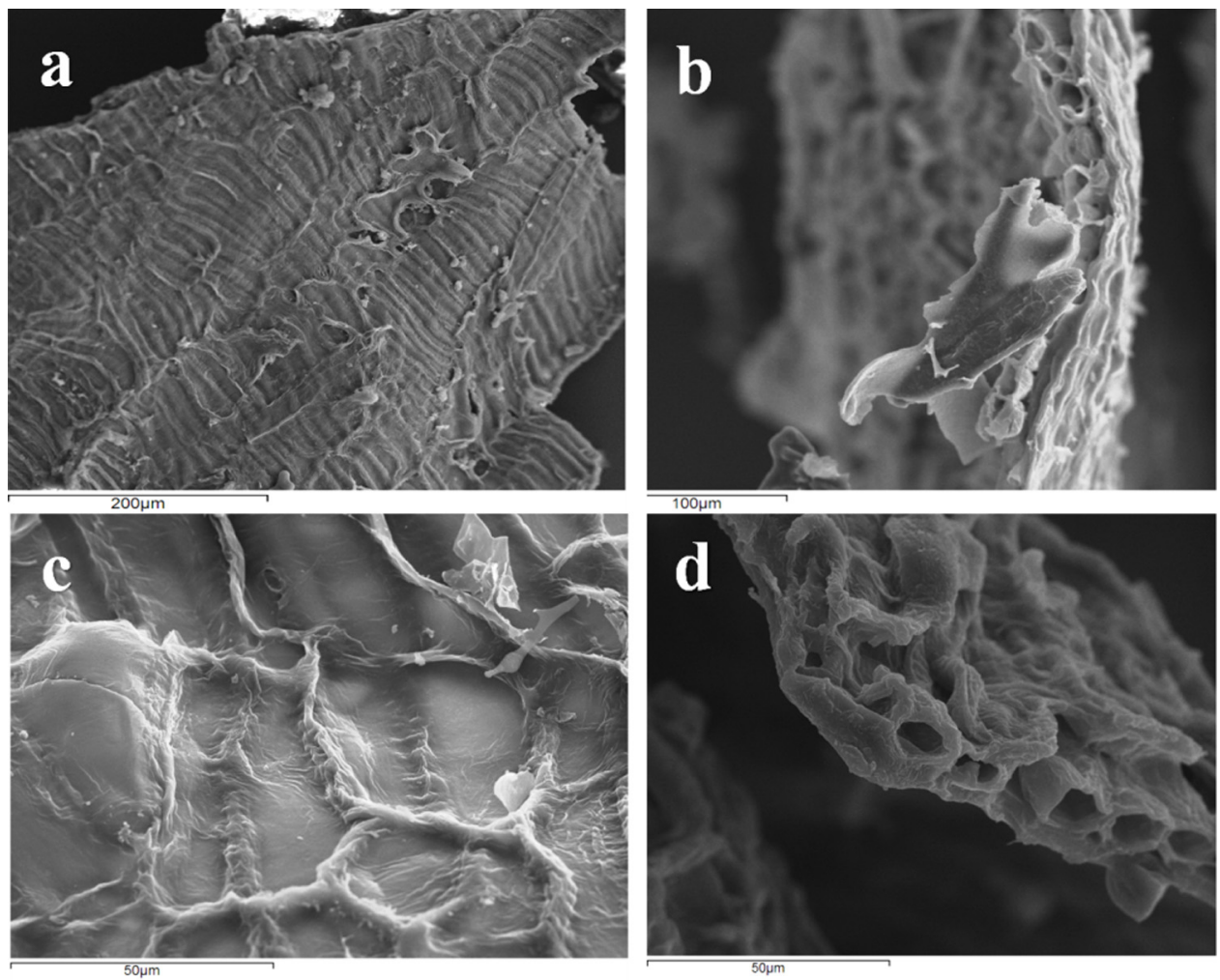

Fig. 3. SEM images of the surface of DWB at different magnifications $[(a) \times 200 ;(b) \times 300 ;(c) \times 1000 ;(d) \times 1000]$.
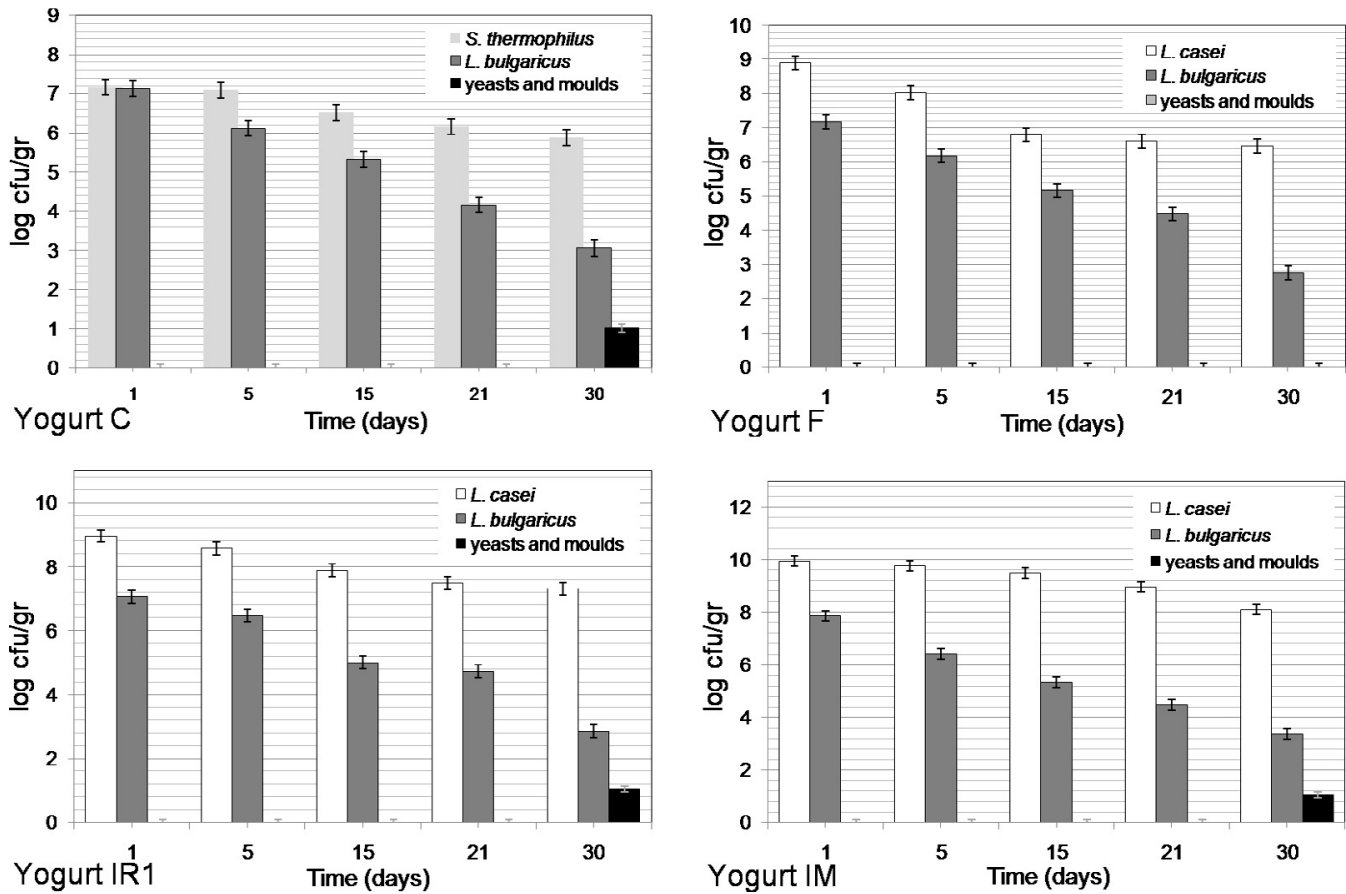

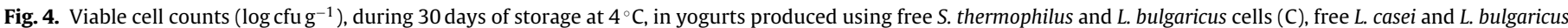
cells (F), and immobilized $L$. casei and L. bulgaricus removed ( $\left.\mathrm{IR}_{1}\right)$ or retained in yogurt (IM) after fermentation.

3-hydroxy-butanone is formed by the reduction of diacetyl and is thought to contribute to the delicate and full flavor and aroma of yogurt, although it is mainly produced by the activity of viable LAB cells during refrigerated storage. In general, ketones are common constituents of yogurt formed by the b-oxidation of saturated fatty acids followed by the decarboxylation of b-ketoacids [40]. Acetone, 2,3-pentanedione, and 2-heptanone were detected in all samples; in addition, 2-nonanone was detected in all samples except the last three fermentation batches of IR yogurts. Acetone is usually the main ketone found in yogurts, whereas higher ketones can be responsible for heated milk flavor [40]. 

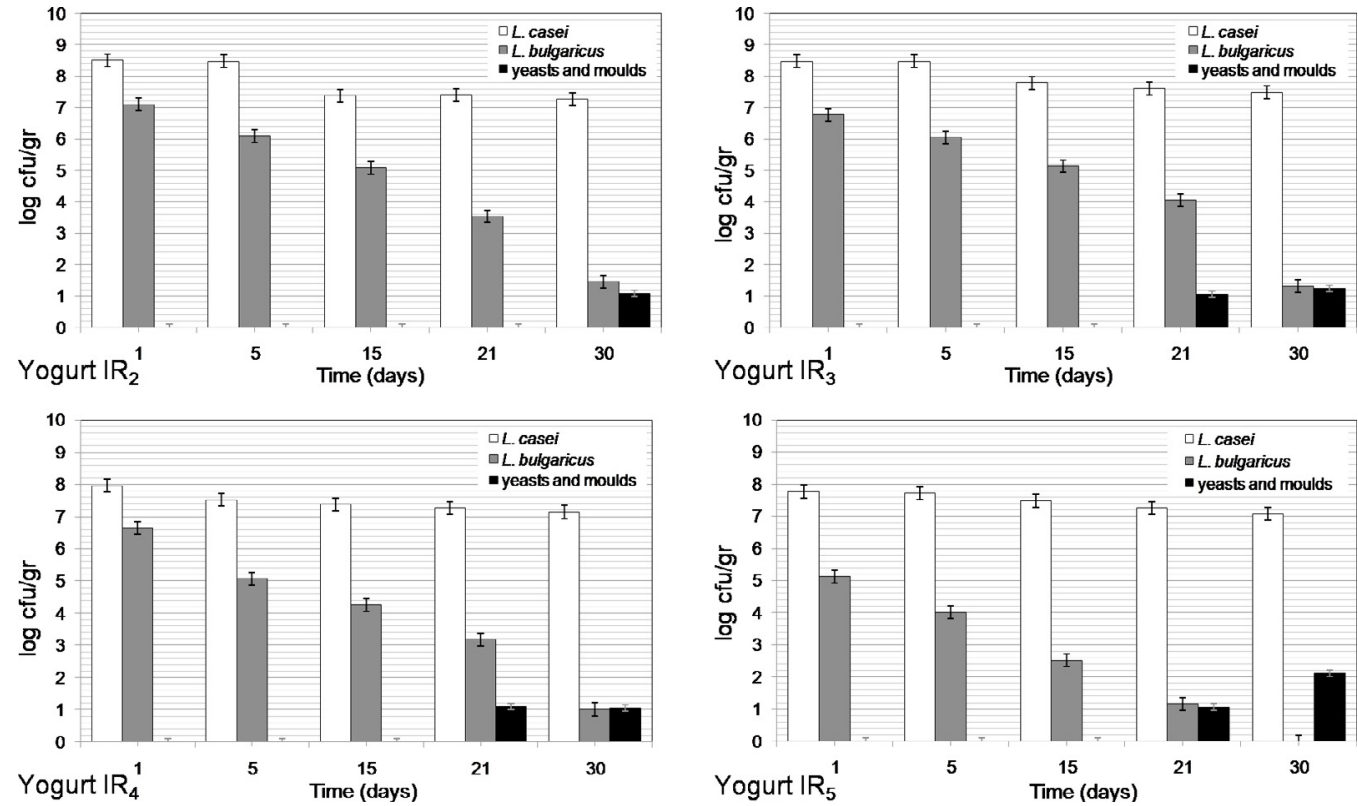

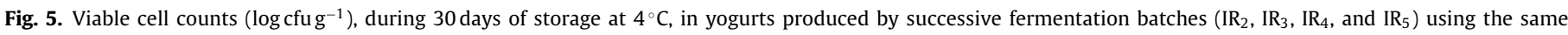
biocatalyst (immobilized $L$. casei and $L$. bulgaricus cells).

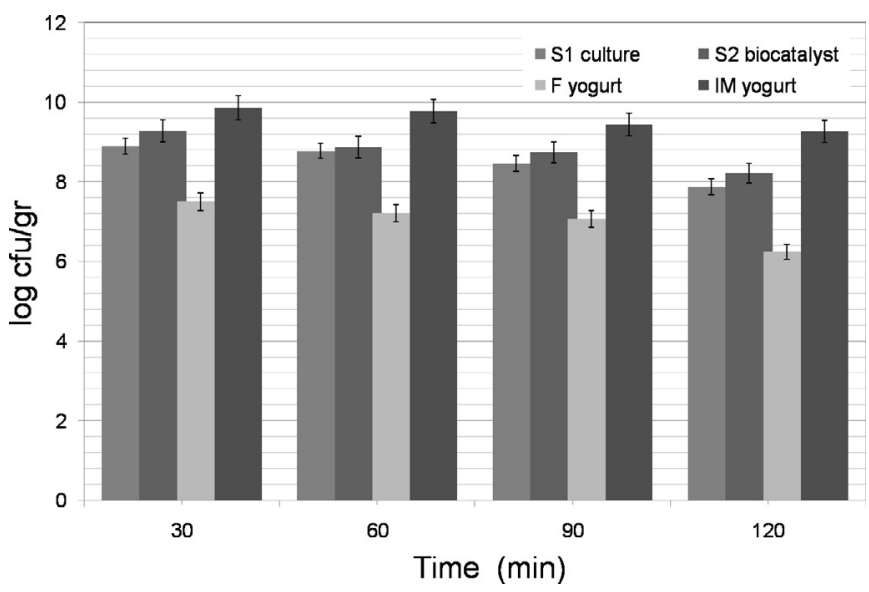

Fig. 6. Effect of exposure to simulated gastric juice $(\mathrm{pH} 3)$ on the survival of free or immobilized $L$. casei cells in biocatalysts and final yogurt products (S1: L. casei culture; S2: immobilized $L$. casei biocatalyst; F: yogurt produced using free $L$. casei and L. bulgaricus cells; IM: yogurt produced using immobilized L. casei and L. bulgaricus biocatalyst).

The results showed that a plethora of aromatic compounds were formed by the action of free and immobilized $L$. casei and L. bulgaricus cells compared to the control samples. However, the relationship between the microorganisms and the chemical compounds is not easy to interpret because of the complexity of microbial interactions. Nevertheless, the results indicate that the use of wheat bran as immobilization support leads to enhanced aromatic profile of yogurt, which is in agreement with the sensory evaluation results.

\section{Conclusions}

In the present study, the production of yogurt using a probiotic L. casei strain in combination with a selected L. bulgaricus strain, both immobilized on DWB, was reported. The results showed that wheat bran favored the viability of both microorganisms, which were maintained at high viable cell numbers during storage at $4{ }^{\circ} \mathrm{C}$. In yogurt produced using immobilized cells, the $\mathrm{pH}$ remained at acceptable levels, whereas quantitative headspace SPME GC/MS analysis of volatile compounds showed a more complex aroma profile, which was in agreement with the sensory evaluations. The results support the potential of lactobacilli immobilized on DWB as ready-to-use freeze-dried biocatalysts for good-quality probiotic yogurt production. The immobilization technique used in this study is simple and of low cost, and no cryoprotectants were used during freeze-drying. The immobilized probiotic starter culture can also improve the nutritional value of yoghurt as a symbiotic. The use of such starters may have an effect on food production because of the valorization of industrial by-products such as wheat bran and the health benefits they can impart, indicating a high commercialization potential.

\section{Acknowledgments}

This project was implemented under the "ARISTEIA" Action of the "OPERATIONAL PROGRAMME EDUCATION AND LIFELONG LEARNING" and was co-funded by the European Social Fund (ESF) and Greek National Resources.

\section{References}

[1] R. Fuller, G. Gibson, Probiotics and prebiotics, in: Definition and Role A2 Caballero, Benjamin, Encyclopedia of Human Nutrition, Second edition, Elsevier, Oxford, 1998, pp. 1633-1639.

[2] G. Bultosa, Functional Foods: Dietary Fibers, Prebiotics, Probiotics, and Synbiotics, Reference Module in Food Science, Elsevier, 2016.

[3] R.A. Rastall, V. Maitin, Prebiotics and synbiotics: towards the next generation, Curr. Opin. Biotechnol. 13 (5) (2002) 490-496.

[4] R.K. Robinson, Fermented milks, in: Yogurt: Role of Starter Culture A2 ? Fuquay, John W, Encyclopedia of Dairy Sciences, Second edition, Academic Press, San Diego, 2002, pp. 529-532.

[5] V. Schoina, A. Terpou, G. Angelika-Ioanna, A. Koutinas, M. Kanellaki, L. Bosnea, Use of Pistacia terebinthus resin as immobilization support for Lactobacillus casei cells and application in selected dairy products, J. Food Sci. Technol. 52 (9) (2014) 5700-5708.

[6] L.A. Bosnea, T. Moschakis, P.S. Nigam, C.G. Biliaderis, Growth adaptation of probiotics in biopolymer-based coacervate structures to enhance cell viability, LWT Food Sci. Technol. 77 (2017) 282-289.

[7] M. Xu, F. Gagné-Bourque, M.-J. Dumont, S. Jabaji, Encapsulation of Lactobacillus casei ATCC 393 cells and evaluation of their survival after freeze-drying, storage and under gastrointestinal conditions, J. Food Eng. 168 (2016) 52-59. 
[8] A. Terpou, A.-I. Gialleli, A. Bekatorou, D. Dimitrellou, V. Ganatsios, E. Barouni, A.A. Koutinas, M. Kanellaki, Sour milk production by wheat bran supported probiotic biocatalyst as starter culture, Food Bioprod. Process. 101 (2017) 184-192.

[9] L.A. Bosnea, Y. Kourkoutas, N. Albantaki, C. Tzia, A.A. Koutinas, M. Kanellaki, Functionality of freeze-dried L. casei cells immobilized on wheat grains, LWT Food Sci. Technol. 42 (10) (2009) 1696-1702.

[10] Y. Kourkoutas, L. Bosnea, S. Taboukos, C. Baras, D. Lambrou, M. Kanellaki, Probiotic cheese production using lactobacillus casei cells immobilized on fruit pieces, J. Dairy Sci. 89 (5) (2006) 1439-1451.

[11] E.W. Ng, M. Yeung, P.S. Tong, Effects of yogurt starter cultures on the surviva of Lactobacillus acidophilus, Int. J. Food Microbiol. 145 (1) (2011) 169-175.

[12] D. Charalampopoulos, R. Wang, S.S. Pandiella, C. Webb, Application of cereals and cereal components in functional foods: a review, Int. J. Food Microbiol. 79 (1-2) (2002) 131-141.

[13] M. Prückler, S. Siebenhandl-Ehn, S. Apprich, S. Höltinger, C. Haas, E. Schmid, W. Kneifel, Wheat bran-based biorefinery 1: composition of wheat bran and strategies of functionalization, LWT Food Sci. Technol. 56 (2) (2014) 211-221.

[14] C.D. Nandini, P.V. Salimath, Carbohydrate composition of wheat, wheat bran, sorghum and bajra with good chapati/roti (Indian flat bread) making quality, Food Chem. 73 (2) (2001) 197-203.

[15] A. Caprez, E. Arrigoni, R. Amadò, H. Neukom, Influence of different types of thermal treatment on the chemical composition and physical properties of wheat bran, J. Cereal Sci. 4 (3) (1986) 233-239.

[16] A.A. Koutinas, V. Sypsas, P. Kandylis, A. Michelis, A. Bekatorou, Y. Kourkoutas, C. Kordulis, A. Lycourghiotis, I.M. Banat, P. Nigam, R. Marchant, M. Giannouli, P. Yianoulis, Nano-Tubular cellulose for bioprocess technology development PLoS One 7 (4) (2012) e34350.

[17] N. Tharmaraj, N.P. Shah, Selective enumeration of lactobacillus delbrueckii ssp. bulgaricus, streptococcus thermophilus, lactobacillus acidophilus, bifidobacteria, lactobacillus casei, lactobacillus rhamnosus, and propionibacteria, J. Dairy Sci. 86 (7) (2003) 2288-2296.

[18] I. Mainville, Y. Arcand, E.R. Farnworth, A dynamic model that simulates the human upper gastrointestinal tract for the study of probiotics, Int. J. Food Microbiol. 99 (3) (2005) 287-296.

[19] L. Koontz, Chapter one - TCA precipitation, in: L. Jon (Ed.), Methods in Enzymology, Academic Press, 2014, pp. 3-10.

[20] D. Dimitrellou, P. Kandylis, M. Sidira, A.A. Koutinas, Y. Kourkoutas, Free and immobilized Lactobacillus casei ATCC 393 on whey protein as starter cultures for probiotic Feta-type cheese production, J. Dairy Sci. 97 (8) (2014) 4675-4685.

[21] D. Dimitrellou, Y. Kourkoutas, I.M. Banat, R. Marchant, A.A. Koutinas, Whey-cheese production using freeze-dried kefir culture as a starter, J. Appl. Microbiol. 103 (4) (2007) 1170-1183.

[22] M. Sidira, D. Dimitrellou, M. Kanellaki, Y. Kourkoutas, Volatile Compounds of Probiotic Fermented Sausages Produced Using Immobilized L. Casei on Wheat, Recent Advances in Food and Flavor Chemistry: Food Flavor and Encapsulation, Health Benefits, Analytical Methods, and Molecular Biology of Functional Foods, 2010, pp. 178-184.

[23] G. Saxami, P. Ypsilantis, M. Sidira, C. Simopoulos, Y. Kourkoutas, A. Galanis, Distinct adhesion of probiotic strain Lactobacillus casei ATCC 393 to rat intestinal mucosa, Anaerobe 18 (4) (2012) 417-420.
[24] G. Broeckx, D. Vandenheuvel, I.J.J. Claes, S. Lebeer, F. Kiekens, Drying techniques of probiotic bacteria as an important step towards the development of novel pharmabiotics, Int. J. Pharm. 505 (1-2) (2016) 303-318.

[25] K.-N. Chen, M.-J. Chen, J.-R. Liu, C.-W. Lin, H.-Y. Chiu, Optimization of incorporated prebiotics as coating materials for probiotic microencapsulation, J. Food Sci. 70 (5) (2005) M260-M266.

[26] D. Li, J. Li, F. Zhao, G. Wang, Q. Qin, Y. Hao, The influence of fermentation condition on production and molecular mass of EPS produced by Streptococcus thermophilus 05-34 in milk-based medium, Food Chem. 197 (Part A) (2016) 367-372.

[27] G.A. Birollo, J.A. Reinheimer, C.G. Vinderola, Viability of lactic acid microflora in different types of yoghurt, Food Res. Int. 33 (9) (2000) 799-805.

[28] R.I. Dave, N.P. Shah, Viability of yoghurt and probiotic bacteria in yoghurts made from commerical starter cultures, Int. Dairy J. 7 (1) (1997) 31-41.

[29] N.P. Shah, Probiotic bacteria: selective enumeration and survival in dairy foods, J. Dairy Sci. 83 (4) (2000) 894-907.

[30] E. Mani-López, E. Palou, A. López-Malo, Probiotic viability and storage stability of yogurts and fermented milks prepared with several mixtures of lactic acid bacteria, J. Dairy Sci. 97 (5) (2014) 2578-2590.

[31] D. Dimitrellou, P. Kandylis, Y. Kourkoutas, Physicochemical and microbiological characteristics of probiotic yogurts produced with immobilized cells, J. Biotechnol. 185 (2014) S79, Supplement.

[32] P.A.M. Hartwig, M.R. McDaniel, Flavor characteristics of lactic, malic, citric, and acetic acids at various pH levels, J. Food Sci. 60 (2) (1995) 384-388.

[33] M.n. Buffa, B. Guamis, J. Saldo, A.J. Trujillo, Changes in organic acids during ripening of cheeses made from raw, pasteurized or high-pressure-treated goats' milk, LWT Food Sci. Technol. 37 (2) (2004) 247-253.

[34] M.P.d. Costa, B.S.d. Frasao, B.R.C.d.C. Lima, B.L. Rodrigues, C.A.C. Junior, Simultaneous analysis of carbohydrates and organic acids by HPLC-DAD-RI for monitoring goat's milk yogurts fermentation, Talanta 152 (2016) 162-170.

[35] I. Salmerón, K. Thomas, S.S. Pandiella, Effect of potentially probiotic lactic acid bacteria on the physicochemical composition and acceptance of fermented cereal beverages, J. Funct. Foods 15 (2015) 106-115.

[36] J.K. Mugula, S.A.M. Nnko, J.A. Narvhus, T. Sørhaug, Microbiological and fermentation characteristics of togwa, a Tanzanian fermented food, Int. J. Food Microbiol. 80 (3) (2003) 187-199.

[37] J. Pico, J. Bernal, M. Gómez, Wheat bread aroma compounds in crumb and crust: a review, Food Res. Int. 75 (2015) 200-215.

[38] D. Beshkova, E. Simova, G. Frengova, Z. Simov, Production of flavour compounds by yogurt starter cultures, J. Ind. Microbiol. Biotechnol. 20 (3-4) (1998) 180-186.

[39] M.N. Nor Qhairul Izzreen, Å.S. Hansen, M.A. Petersen, Volatile compounds in whole meal bread crust: the effects of yeast level and fermentation temperature, Food Chem. 210 (2016) 566-576.

[40] S. Kaminarides, P. Stamou, T. Massouras, Comparison of the characteristics of set type yoghurt made from ovine milk of different fat content, Int. J. Food Sci. Technol. 42 (9) (2007) 1019-1028. 